\title{
Effect of Shelf life on Germination Percentage and Some Nutritional Value of Germinated Native Black Rice
}

\author{
Naruemon Mongkontanawat ${ }^{1 *}$ and Saranrat Phuangborisut ${ }^{1}$ \\ ${ }^{1}$ Department of Product Development and Management Technology, Faculty of Agro-Industrial Technology, \\ Rajamangala University of Technology Tawan-ok ,Chanthaburi campus, Chanthaburi, Thailand 22210 \\ *jeabn2009@gmail.com
}

\begin{abstract}
Native black rice(KhaoHawm Mae Paya Tong Dam) was studied on germination percentage (\%) and length of roots when storage time was increased at 1, 2, 3, 4, 5 and 6 months, respectively. The result found that \% germination and length of roots exhibited a decrease at the end of storage $(93.92 \pm 0.63,89.00 \pm 0.70 \%$ and $1.54 \pm 0.07,1.42 \pm 0.53 \mathrm{~mm}$ at 1 and 6 months of storage, respectively). Then, some nutritional values of germinated native black rice werealso evaluated. The result indicated that $\gamma$-aminobutyric acid had increased slightly when the storage time was longer $(9.01 \pm 0.43,9.09 \pm 0.07$ and $10.82 \pm 0.14 \mathrm{mg} / 100 \mathrm{~g}$ at 1,3 , and $5 \mathrm{months}$ of storage, respectively). However, vitamin B1, protein content, antioxidant activity (DPPH scavenging activity assay) and phenolic compounds decreased when the shelf lifewas longer $(0.78 \pm 0.01,0.73 \pm 0.04$ and0.54 \pm 0.00 $\mathrm{mg} / 100 \mathrm{~g} ; 13.40 \pm 0.03,12.95 \pm 0.11$ and $12.99 \pm 0.05 \mathrm{~g} / 100 \mathrm{~g} ; \mathrm{IC}_{50} 22.15 \pm 0.17,36.34 \pm 5.47$ and $36.47 \pm 4.59 \mathrm{mg} / \mathrm{ml}$; $16.07 \pm 0.14,15.91 \pm 0.32$ and $14.57 \pm 0.10 \mathrm{mg} \mathrm{GAE} / \mathrm{ml}$ at shelf life of 1,3 , and 5 months, respectively). In contrast, the moisture content still increased significantly $(p \leq 0.05)(7.68 \pm 0.08$ and $8.74 \pm 0.07 \%$ at 1 and 6 months of storage, respectively). In conclusion, the finding from this research could be used as a suggestion guideline forrice consumptionas well as to control the quality of germinated nativeblack rice.
\end{abstract}

Keywords: Native black rice, $\gamma$-aminobutyric acid (GABA), antioxidant activity

\section{Introduction}

Rice (Oryza sativa L.) is the staple food for more than half of the world's population including Thailand [1]. In fact, Thai farmers grow rice in many areas of Thailand, particularly in Chanthaburi province. Native black rice (Khao Hawm Mae Paya Tong Dam) is a traditional rice plant variety in Amphur Kao Kitchakut, Chanthaburi province. The pigment of this rice is black. In pigmented rice, there is a natural colorant; anthocyanin, which is reported to possess a free radical scavenging activity [2]. In addition, black rice contains more nutritional components such as dietary fibers, phytic acid, vitamin E, and vitamin B than the ordinary milled rice [3]. Moreover, Sangkitikomon et al.(2008) reported that anthocyanin from black rice was found to have higher antioxidant activity than red rice and rice berry [4]. From the nutritional point of view, black rice is the most famous and generally used ingredient in snack and desserts [5]. Germinated black rice offers more considerable benefit. Especially that it had an increasingin GABA, dietary fiber, inositols, ferulic acid, phytic acid, tocotrienols, magnesium, potassium, zinc, $\gamma$-oryzanol, and prolylendopeptidase inhibitor. GABA is a neurotransmitter in the brain and the spinal cord of mammals. This substance can lower hypertension, promote sleepiness and has the benefit for human health [6]. Additionally, the germination of black rice frees it bound minerals, making them more absorbable by the body and the rice is tenderer and tastier since black rice is a rich source of nutritional value and high antioxidant activity[7]. On the other hand, no information regarding the effect of shelf life on germinated percentage and some nutritional values of germinated native black rice has been reported yet. Therefore, the purpose of this study was to investigate the effectof shelf lifeon germinated percentage, length of roots, and some nutritional values of germinated native black rice. 


\section{Materials and method}

\subsection{Materials}

Native black rice (Khao Hawm Mae Paya Tong Dam) was purchased from a local farmer in Amphur Kao Kitchakut, Chanthaburi province in Thailand and transported to the laboratory.

\subsection{Germinated native black rice preparation}

Germinated native black rice was prepared according to modified methods described by Panyanak et al. (2010) [8]. Briefly, the sample was selected and soaked in water at the ratio of rice and water(1:10) at $40^{\circ} \mathrm{C}$ for 6 hours in the tray. The water was drained and the samples were incubated for 24 hours. The germination was stopped by drying using a hot air oven, at $55^{\circ} \mathrm{C}$ for 4.5 hours. Then, the obtained germinated native black rice wasstored at room temperature $\left(30^{\circ} \mathrm{C}\right)$ and monitored forgermination percentage, length of roots, moisture content, and phenolic compounds as shelf life was increased at 1,2, 3, 4, 5, and 6 months, respectively. Finally, the obtained germinated native black rice wasalso investigated for $\gamma$-aminobutyric acid, vitamin B1, protein content and antioxidant activity (DPPH scavenging activity assay) when shelf life was increased at 1, 3, and 5 months, respectively.

\subsection{Moisture content determination}

Moisture content evaluation was performed using the method of drying method (AOAC,1990) [9]. Germinated native black rice sample ( $3 \mathrm{~g}$ ) was used in the assessment.

\subsection{Phenolic compound determination}

Phenolic compounds evaluation was investigated according to modified methods described by Wolfe et al. (2005)[10]. Samples $(1 \mathrm{~g})$ were mixed with $500 \mathrm{ul}$ of distilled water and $125 \mathrm{ul}$ of folin reagent. The solution was incubated for $6 \mathrm{~min}$, before adding 1,250 ul of $7 \%$ sodium carbonated and 1,000 ul of distilled water and then the solution was incubated for $90 \mathrm{~min}$. Finally, the absorbance were determined by using spectrophotometer at the wavenumber $760 \mathrm{~nm}$. The phenolic compound were calculated by using standard curve of standard gallic acid.

\section{$2.5 \gamma$-Aminobutyric acid (GABA)determination}

GABA content were sent to analyze by the Institute of Food Research and Product Development (IFRPD), Kasetsart University in Bangkok, Thailand. Briefly,a sample of 2.5 gwas added to $18 \mathrm{ml}$ of distilled water and 2 $\mathrm{ml}$ of 3\% sulfosalicylic acid, respectively. Then, the mixture was stirred for 30 minutes and centrifuged. The supernatant $(0.1 \mathrm{ml})$ was mixed with $0.1 \mathrm{ml}$ of $\mathrm{NaHCO}_{3}$ and $0.40 \mathrm{ml}$ of debsyl-C andthese solutions were mixed together. The solution was heated in water bath at $70^{\circ} \mathrm{C}$ for 10 minutes. The obtained solution wasthen mixed with $0.25 \mathrm{ml}$ of ethanol and $0.25 \mathrm{ml}$ of $0.025 \mathrm{M} \mathrm{KH}_{2} \mathrm{PO}_{2}$. The $\gamma$-aminobutyric acid (GABA)wasvaluated using a High Performance Liquid Chromatography (HPLC)(HPLC-UV detector:agilent, 1,200 serice; column:supercosil LC-DABS, $15 \mathrm{~cm} \times 4.6 \mathrm{~cm}, 3 \mathrm{um}$; flow rate $1 \mathrm{ml} / \mathrm{min}$; mobile phase: gradient $80 \% \mathrm{CH}_{3} \mathrm{COONa} \mathrm{pH} 6.80$, acetonitrile inject volume $5 \mathrm{ul}$; column temperature $40{ }^{\circ} \mathrm{C}$, detector: uv $465 \mathrm{~nm}$ and standard GABA $\geq 99$ $\%)[11]$.

\subsection{Vitamin B1 determination}

Vitamin B1 wasalso sent to analyze by the Institute of Food Research and Product Development (IFRPD) at Kasetsart Universityin Bangkok, Thailand. Briefly,thiamin was extracted according the method of Ndaw et al. (2000)[12]. Before analysis, the samples were filtered through a 0.45 um Millex filter (Millipore). The filtrate was used for chromatographic analysis. The HPLC liquid chromatographic system was a 2690 Alliance Model (waters) with a 2475 fluorescence detector (waters). $\mathrm{A}_{\text {uBondapakC }} \mathrm{C}_{18}$ column $(15 \mathrm{~cm} \mathrm{x} 3.9 \mathrm{~mm}$, waters) with a mobile phase (0.05 M sodium acetate-methanol(30/70; v/v, $\mathrm{pH} 6)$ was used. The separation was evaluated at $30^{\circ} \mathrm{C}$ at a flow rate of $1 \mathrm{ml} / \mathrm{min}$. The injection volume was $20 \mathrm{ul}[13]$.

\subsection{Protein content determination}

Protein content of germinated native black rice was estimated using the Kjeldahl method as reported by AOAC, 1990[9]. 


\subsection{DPPH radical scavenging activity determination}

The free radical scavenging activity wassent to analyze by Kasetsart Agricultural and Agro-Industrial Product Improvement Institute (KAPI) in Bangkok, Thailand. DPPH radical scavenging activity procedure was performed according to the methods described by Zhu et al. (2006)[14]. Briefly, one gram of sample was extracted with $10 \mathrm{ml}$ ethanol. The solution was separated by centrifugation at 6,000 rpm. The obtained supernatant was tested by mixing with ethanol at various concentrationsof $10,20,30,40$, and $50 \mu \mathrm{g} / \mathrm{ml}$. The sample $(1 \mathrm{ml})$ was mixed with $0.1 \mathrm{mM}$ DPPH (2,2-diphenyl-1-picrylhydrazyl) solution in $95 \%$ ethanol (1ml) and incubated in dark condition for 30 minutes. The absorbance was determined using a spectrophotometer at 517 $\mathrm{nm}$. Vitamin C (L-ascorbic acid), Vitamin E (Tocopherol), and BHT (Butylatedhydroxytoluen) were used in the reference standard compound. The percentage of radical scavenging activity was calculated as the following equation:

DPPH radical scavenging activity $(\%)=\left[\left(\mathrm{A}_{0}-\mathrm{A}_{1}\right) / \mathrm{A}_{0}\right] \times 100$

$\mathrm{A}_{0}=$ the absorbance of control reaction

$\mathrm{A}_{1}=$ the absorbance of test compound

The sample concentration providing $50 \%$ inhibition $\left(\mathrm{IC}_{50}\right)$ was calculated from the graph plotting inhibition percentage against the sample concentration.

\subsection{Data analysis}

Physicochemicalcharacteristics analysis was carried out in three replicates while some nutritional values were carried out in duplicates. The data were subjected to analysis of variance (ANOVA) $(p \leq 0.05)$. Mean with significant differences was separated by Duncan's multiple range test (DMRT) using the computer software.

\section{Results and Discussion}

From determination, the effect of shelf life ongermination percentage, length of roots, moisture content, and phenolic compounds of germinated native black rice every month until 6 monthsarepresented in Table1. The level of \%germination of germinated native black ricehad a slightly significant $(\mathrm{p} \leq 0.05)$ decrease when the shelf life was longer.The number of germination percentage $(93.92 \pm 0.13 \%)$ of germinated native black rice at 1 month was higher than at 6 months $(89.00 \pm 0.71 \%)$. In addition, the number of length of roots of germinated native black rice had also slowly decreasesignificantly $(\mathrm{p} \leq 0.05)$ when the shelf lifewas longer. The number of length of roots $(1.54 \pm 0.07 \mathrm{~mm})$ of germinated black rice at storage time of 1 month was higher than of 6 months $(1.42 \pm 0.53 \mathrm{~mm})$. Moreover, the level of phenolic compounds of germinated native black ricewas significantly

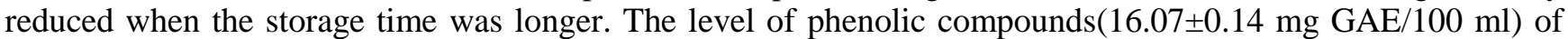
germinated black rice at storage timeof 1 month was higher than of 6 months $(14.00 \pm 0.28 \mathrm{mg} \mathrm{GAE} / 100 \mathrm{ml})$.The finding in this study was in agreement with the earlier reports. Zhou et al. (2004) also found that a reduction in the content of bound phenolic acids in brown and white rice was higher at $37^{\circ} \mathrm{C}$ than at $4{ }^{\circ} \mathrm{C}$ during the storage [15].In contrast, the value of moisture content of germinated native black rice had significantly $(\mathrm{p} \leq 0.05)$ increased during longer storage period. The value of moisture content $(7.68 \pm 0.08 \% \mathrm{w} / \mathrm{w})$ of germinated native black rice at 1 month showed lower than at 6 months $(8.74 \pm 0.07 \% \mathrm{w} / \mathrm{w})$

TABLE 1 .Effect of Shelf Life on Germination Percentage, Length of roots, Moisture content and Phenolic compounds of Germinated Native Black Rice

\begin{tabular}{cllll}
\hline \hline $\begin{array}{c}\text { Shelf life } \\
\text { (month) }\end{array}$ & \%Germination & $\begin{array}{l}\text { Length of roots } \\
(\mathrm{mm})\end{array}$ & $\begin{array}{l}\text { Moisture } \\
\text { content } \\
(\% \mathrm{w} / \mathrm{w})\end{array}$ & $\begin{array}{l}\text { Phenolic compounds(mg } \\
\text { GAE/100 ml) }\end{array}$ \\
\hline 1 & $93.92 \pm 0.13^{\mathrm{a}}$ & $1.54 \pm 0.07^{\mathrm{a}}$ & $7.68 \pm 0.08^{\mathrm{b}}$ & $16.07 \pm 0.14^{\mathrm{a}}$ \\
2 & $93.50 \pm 1.41^{\mathrm{a}}$ & $1.51 \pm 0.44^{\mathrm{ab}}$ & $8.36 \pm 0.45^{\mathrm{a}}$ & $16.02 \pm 0.11^{\mathrm{a}}$ \\
3 & $93.25 \pm 1.76^{\mathrm{a}}$ & $1.46 \pm 0.42^{\mathrm{bc}}$ & $8.69 \pm 0.50^{\mathrm{a}}$ & $15.92 \pm 0.32^{\mathrm{a}}$ \\
4 & $93.25 \pm 0.35^{\mathrm{a}}$ & $1.44 \pm 0.40^{\mathrm{c}}$ & $8.76 \pm 0.43^{\mathrm{a}}$ & $14.90 \pm 0.10^{\mathrm{b}}$ \\
5 & $90.25 \pm 1.76^{\mathrm{b}}$ & $1.42 \pm 0.48^{\mathrm{bc}}$ & $8.77 \pm 0.11^{\mathrm{a}}$ & $14.57 \pm 0.10^{\mathrm{b}}$ \\
6 & $89.00 \pm 0.71^{\mathrm{b}}$ & $1.42 \pm 0.53^{\mathrm{bc}}$ & $8.74 \pm 0.07^{\mathrm{a}}$ & $14.00 \pm 0.28^{\mathrm{c}}$ \\
\hline \hline
\end{tabular}

Mean values \pm standard deviation $(n=3)$ with different letters are statistically different $(\mathrm{p} \leq 0.05)$ according to Duncan's multiple range test (DMRT) 
From determination, the effect of shelf life on some nutritional values of germinated native black riceat 1,3 , and 5 months, respectively are exhibited in Table2.The level of $\gamma$-aminobutyric acid (GABA) had increased with a significant difference $(\mathrm{p} \leq 0.05)$ when the storage time was longer. GABA content $(10.82 \pm 0.14 \mathrm{mg} / 100 \mathrm{~g})$ of germinated native black rice at 5 months was higher than at 1 month $(9.01 \pm 0.43 \mathrm{mg} / 100 \mathrm{~g})$. However, the value of vitamin B1 of germinated native black rice had significantly $(\mathrm{p} \leq 0.05)$ decreased when the storage time was longer. The level of vitamin B1 $(0.54 \pm 0.00 \mathrm{mg} / 100 \mathrm{~g})$ of germinated native black rice at 5 months was lower than at 1 month $(0.78 \pm 0.01 \mathrm{mg} / 100 \mathrm{~g})$. The results of this study agreed with Rehman (2006), who had studied the effect of storage on nutrition quality of commonly consumed cereals. He had also found that the thiamin content of rice had gradually declinedin six month's storage[16]. In addition, the level of protein content of germinated native black rice also decreased when the storage time was longer. On the other hand, non-significant $(\mathrm{p} \leq 0.05)$ difference was exhibited. The level of protein content $(13.04 \pm 0.03 \mathrm{~g} / 100 \mathrm{~g})$ of germinated black rice at storage of 1 month was a little higher than at 5 months $(12.99 \pm 0.05 \mathrm{~g} / 100 \mathrm{~g})$. Moreover, the antioxidant activity (DPPH scavenging activity) decreased when the storage time was longer. The number of $\mathrm{IC}_{50}$ (concentrationthat inhibited the growth by $50 \%)(22.15 \pm 0.17 \mathrm{mg} / \mathrm{ml})$ of germinated black ricestoredat 1 month was significantly lower than at 5 months $(36.47 \pm 4.59 \mathrm{mg} / \mathrm{ml})$. From these results, it could be explained that phenolic compounds were mainly responsible for the antioxidant activity of rice grains [17]since the level of phenolic compounds decreased during prolonged storage period. Therefore, the antioxidant activity of germinated black rice had reduced as found in this research.

TABLE 2.Effect of Shelf Life on Some Nutritional Value of Germinated Native Black Rice

\begin{tabular}{cllll}
\hline \hline $\begin{array}{c}\text { Shelf life } \\
\text { (month) }\end{array}$ & $\begin{array}{c}\gamma \text {-Aminobutyric } \\
\text { acid }(\mathrm{mg} / 100 \mathrm{~g})\end{array}$ & $\begin{array}{l}\text { Vitamin } \\
\mathrm{B} 1(\mathrm{mg} / 100 \mathrm{~g})\end{array}$ & $\begin{array}{l}\text { Protein } \\
\text { content }^{\mathrm{ns}} \\
(\mathrm{g} / 100 \mathrm{~g})\end{array}$ & $\mathrm{IC}_{50}(\mathrm{mg} / \mathrm{ml})$ \\
\hline 1 & $9.01 \pm 0.43^{\mathrm{b}}$ & $0.78 \pm 0.01^{\mathrm{a}}$ & $13.04 \pm 0.03$ & $22.15 \pm 0.17^{\mathrm{b}}$ \\
3 & $9.09 \pm 0.07^{\mathrm{b}}$ & $0.73 \pm 0.04^{\mathrm{a}}$ & $12.95 \pm 0.11$ & $36.34 \pm 5.47^{\mathrm{a}}$ \\
5 & $10.82 \pm 0.14^{\mathrm{a}}$ & $0.54 \pm 0.00^{\mathrm{b}}$ & $12.99 \pm 0.05$ & $36.47 \pm 4.59^{\mathrm{a}}$ \\
\hline \hline
\end{tabular}

Mean with different letters are statistically different ( $\mathrm{p} \leq 0.05)$ according to Duncan's multiple range test (DMRT)

Bars represent standard deviation from duplicate determination and triplicate determination in the value of $\mathrm{IC}_{50}$

\section{Conclusion}

The results indicated that the germination percentage, length of roots, phenolic compounds, vitamin B1, protein content, and antioxidant activity of germinated native black rice decreased whilethe level of moisture content and $\gamma$-aminobutyric acidshown a significant increase when shelf life was prolonged. In summary,the finding from this research could be used as a suggestion guideline for rice consumptionas well as to control the quality of germinated native black rice. Based on the potential beneficial effects on health, the consumer should eat germinated native black rice that had been stored for a short period of time. However, if they would like to receive high amount of $\gamma$-aminobutyric acid, native rice that had been stored longer should be consumed instead.

\section{Acknowledgements}

The authors would like to thank Rajamangala University of Technology Tawan-ok for the financial support of this research.

\section{References}

[1] S. Chanta, P. Prathepha, and B. Jongdee, "Nuances of traditional in utilization of rice landraces by a farming community in North-Eastern Thailand,'Indian Journal of Traditional Knowledge, vol.13, no. 3, pp. 473-483, 2014.

[2] T. Oki, M. Masuda, M. Kobayashi, Y. Nishiba, S. Furuta, I. Suda, and T. Sato, "Polymeric procyanidins as radicalscavenging components in red hulled rice,”Journal of Agricultural and Food Chemistry, vol. 50, pp.7524-7529, 2002.

https://doi.org/10.1021/jf025841z 
[3] J. Banchuen, P. Thammarutwasik, B. Ooraikul, P. Wuttijumnong, and P. Sirivongpaisal, "Increasing the bio-active compounds contents by optimizing the germination conditions of Southern Thai Brown Rice," Songklanakarin Journal of Science and Technology, vol. 32, no. 3, pp. 219-230, 2010.

[4] V. Sangkitikomon, T. Tentumnou, and A. Rodchanasasod, "Comparisions of total antioxidants of red rice, black rice and black sticky rice,”Journal of nutrition, vol. 43, no. 2, pp. 16-21, 2008.

[5] K. Tananuwong, and W. Tewaruth, "Extraction and application of antioxidants from black glutinous rice,"LWT-Food Science Technology, vol. 43, pp. 476-481, 2010.

https://doi.org/10.1016/j.Iwt.2009.09.014

[6] T. Okada, T. Sugishita, T. Murakami, H. Murai, T. Saikusa, and T. Horio, "Effect of the defatted rice germ enrich with GABA for sleepless, depression, autonomic disorder by oral administration,’Journal of the Japanese Society for Food Science and Technology, vol. 47, pp. 596-603, 2000.

https://doi.org/10.3136/nskkk.47.596

[7] H. Karahara, Germinated brown rice, Department of Sciences of Functional Food, Shinshu University, Japan, 2004, pp. $1-32$.

[8] P. Panyanak, S. Suwanketnikom, S. Tonhang, and W. Siripoonwiwat, "Correlations between seed characteristics, seed germination and $\gamma$-aminobutyric acid (GABA) content of 14 rice cultivars,'Thai Journal of Botany, vol. 2 (Special Issue), pp. 97-113, 2010.

[9] AOAC, Official method of analysis vol 1, $15^{\text {th }}$ Ed,Verginia, USA, Association of Official Analytical Chemist Inc., 1990, pp. 69-75.

[10] K.Wolfe,K, X. Wu, and R.H. Liu, “Antioxidant activity of apple peels,”Journal of Agricultural and Food Chemistry, vol. 51, pp. 609-614, 2003.

https://doi.org/10.1021/jf020782a

[11] A. Tadashi, K. Yoshiatsu, Y.Wen Bin, and Toshihiko, "High performance liquid chromatographic determination of $\beta$ alanine, $\beta$-aminoisobutyric acid and $\gamma$-aminobutyric acid in tissue extracts and urine of normal and caminooxy acetatetreated rats," Journal of Chromatography B, vol. 712, pp. 43-49, 1998.

https://doi.org/10.1016/S0378-4347(98)00154-6

[12] S. Ndaw, M. Bergaentzle, D. Aoude-Werner, and C., Hasselmann, "Extraction procedures for liquid chromatographic determination of thiamin, riboflavin and vitamin B6 in foodstuffs,"'Food Chemistry, vol. 71, pp.129-138, 2000.

https://doi.org/10.1016/S0308-8146(00)00135-7

[13] F. Batifoulier, M.A. Verny, Chanliaud, E., C. Remesy, and C. Demigne, "Effect of different breadmakingmehods on thiamine, riboflavin and pyridoxine contents of bread,'Journal of Cereal Science, vol. 42, pp 101-108, 2005. https://doi.org/10.1016/j.jcs.2005.03.003

[14] K., Zhu, H. Zhou, and H. Qian, “Antioxidant and free radical scavenging activities of wheat germ protein hydrolysates (WGPH) prepared with catalase,’Process Biochemistry, vol. 41,pp.1296-1302, 2006. https://doi.org/10.1016/j.procbio.2005.12.029

[15] Z. Zhou, K. Robards, S. Helliwell, and C. Blanchard, "The distribution of phenolic acids in rice," Food Chemistry, vol. 87, pp. 401-406, 2004. https://doi.org/10.1016/j.foodchem.2003.12.015

[16] Z.U. Rehman, "Storage effects on nutritional quality of commonly consumed cereals," Food Chemistry, vol. 95, pp. 53$57,2006$. https://doi.org/10.1016/j.foodchem.2004.12.017

[17] F.D. Goffman, and C.J. Bergman, "Rice kernel phenolic content and its relationship with antiradical efficiency,"Journal ofScicence and Food Agriculture, vol. 84, pp.1235-1240, 2004. 